venience to the staff of the Asylum, the work of the institution has gone on alinost as usual.

The origin of the fire is still a mystery. The flames could be seen for miles around, and soon after the fire began several hundreds of people assembled outside the building.

The damage is partly corered by insurance.

A. F. M.

\title{
Obituary.
}

\section{JOHN DALE HEWSON, L.R.C.P. LOND.}

In recording in this Journal the death of a well-known member of our Association, the late Medical Superintendent of the Coton Hill Asylum, Stafford, we cannot express the sentiments of those who knew him, better than in the following brief notice which appeared in the "Staffordshire Advertiser":-

THE LATB DR. HEwsON. - To a wide circle of friends in this county, and also in the county of Wilts, the death of Dr. Hewson, the Medical Superintendent of Coton Hill Aeglum, which took place on the 10th inst., has bronght deep sorrow and a sense of irreparable loss. He was appointed to his office in 1853, and had just entered upon his 31st year of service. When he first came to Stafford the building at Coton Hill was not completed, but early in 1854 he was prepared to receive his first instalment of patients. He very soon won the entire confidence of his committee, and well did he vindicate that confidence. His skill and derotion brought the place rapidly abreast with the foremost of its class; and now that unfinished pile of brick and mortar which they entrusted to him thirty years ago, his dead hand yields back to them, a full and well. organised institution, second to none in the kingdom. Coton Hill is, in part, a oharitable institation, and Charity herself could not have chosen a kinder hand to dispense her delicate and, in such association, her necessarily secret succour than that of Dr. Hewson. He had for many years a most able, devoted, and considerate coadjutor in his wife. He never thoroughly rallied after the shock of her illness and death, which happened about three years ago, but gradually gave way before the inroad of the disease which finally proved fatal to him. He bore the lassitude and utter helplessness of the closing weeks of his life with much placid and often cheerful resignation, and at the last he passed very peacefully away. Dr. Hewson was one of the most geuial, generous, and openhearted of men, and inspired all who were conversant with him with no common degree of attachment to him. He possessed in a wonderful manner the real, though often unconscious, confidence of those under his charge; and if a sympathy which never faltered under the hardening influence of constant famili. arity with one of the saddest and most inscrutable of human maladies deserved such confidence, well was he worthy of it.- "The Staffordshire Advertiser," Nov. 19th, 1883.

WILLIAM HENRY PARSEY, M.D., B.A. LOND., F.R.C.P. LOND.

At the County Lanatic Asylum, Hatton, near Warwick, on the 10th of Jan. last, died Dr. W. H. Parsey, for more than thirty years the Medical Superintendent of that Institution. During his superintendency the asylum had doubled or trebled in numbers and size, notably by the erection, some thirteen years ago, as an annexe to the lunatic asylum, of a large separate building for the reception of the idiot and imbecile poor of the county.

Dr. Pareey held the degree of M.D. of the University of London, the Fellow. 